\title{
Interactive Effects of Ocean Acidification and Nitrogen- Limitation on the Diatom Phaeodactylum tricornutum
}

\author{
Wei $\mathrm{Li}^{1}$, Kunshan Gao ${ }^{1 *}$, John Beardall ${ }^{2}$ \\ 1 State Key Laboratory of Marine Environmental Science, Xiamen University, Xiamen, China, 2 School of Biological Sciences, Monash University, Clayton, Victoria, Australia
}

\begin{abstract}
Climate change is expected to bring about alterations in the marine physical and chemical environment that will induce changes in the concentration of dissolved $\mathrm{CO}_{2}$ and in nutrient availability. These in turn are expected to affect the physiological performance of phytoplankton. In order to learn how phytoplankton respond to the predicted scenario of increased $\mathrm{CO}_{2}$ and decreased nitrogen in the surface mixed layer, we investigated the diatom Phaeodactylum tricornutum as a model organism. The cells were cultured in both low $\mathrm{CO}_{2}(390 \mu \mathrm{atm})$ and high $\mathrm{CO}_{2}(1000 \mu \mathrm{atm})$ conditions at limiting $\left(10 \mu \mathrm{mol} \mathrm{L}{ }^{-1}\right)$ or enriched $\left(110 \mu \mathrm{mol} \mathrm{L}^{-1}\right)$ nitrate concentrations. Our study shows that nitrogen limitation resulted in significant decreases in cell size, pigmentation, growth rate and effective quantum yield of Phaeodactylum tricornutum, but these parameters were not affected by enhanced dissolved $\mathrm{CO}_{2}$ and lowered $\mathrm{pH}$. However, increased $\mathrm{CO}_{2} \mathrm{Concentration}$ induced higher $\mathrm{rETR}_{\max }$ and higher dark respiration rates and decreased the $\mathrm{CO}_{2}$ or dissolved inorganic carbon (DIC) affinity for electron transfer (shown by higher values for $\mathrm{K}_{1 / 2}$ DIC or $\mathrm{K}_{1 / 2} \mathrm{CO} 2$ ). Furthermore, the elemental stoichiometry (carbon to nitrogen ratio) was raised under high $\mathrm{CO}_{2}$ conditions in both nitrogen limited and nitrogen replete conditions, with the ratio in the high $\mathrm{CO}_{2}$ and low nitrate grown cells being higher by $45 \%$ compared to that in the low $\mathrm{CO}_{2}$ and nitrate replete grown ones. Our results suggest that while nitrogen limitation had a greater effect than ocean acidification, the combined effects of both factors could act synergistically to affect marine diatoms and related biogeochemical cycles in future oceans.
\end{abstract}

Citation: Li W, Gao K, Beardall J (2012) Interactive Effects of Ocean Acidification and Nitrogen-Limitation on the Diatom Phaeodactylum tricornutum. PLoS ONE 7(12): e51590. doi:10.1371/journal.pone.0051590

Editor: Lucas J. Stal, Royal Netherlands Institute of Sea Research (NIOZ), The Netherlands

Received July 19, 2012; Accepted November 5, 2012; Published December 7, 2012

Copyright: (c) $2012 \mathrm{Li}$ et al. This is an open-access article distributed under the terms of the Creative Commons Attribution License, which permits unrestricted use, distribution, and reproduction in any medium, provided the original author and source are credited.

Funding: This study was supported by National Basic Research Program of China (No. 2009CB421207 and 2011CB200902), National Natural Science Foundation (No. 40930846, No. 41120164007), Program for Changjiang Scholars and Innovative Research Team (IRT0941) and China-Japan collaboration project from MOST (S2012GR0290). The funders had no role in study design, data collection and analysis, decision to publish, or preparation of the manuscript.

Competing Interests: The authors have declared that no competing interests exist.

*E-mail: ksgao@xmu.edu.cn

\section{Introduction}

Rising atmospheric $\mathrm{CO}_{2}$ concentrations enhance its absorption into the world's oceans, which currently accounts for removal of nearly one third of anthropogenic $\mathrm{CO}_{2}$ emissions from the atmosphere [1]. Atmospheric $\mathrm{CO}_{2}$ concentrations are expected to reach $800-1000$ ppmv by the end of this century according to the "business as usual" $\mathrm{CO}_{2}$ emission scenario [2]. Dissolution of $\mathrm{CO}_{2}$ into seawater has already induced a global drop in $\mathrm{pH}$ of 0.1 units since the end of the Industrial Revolution, and values are expected to drop another $0.3-0.4$ units by the end of this century. This decline in $\mathrm{pH}$ driven by increased $\mathrm{CO}_{2}$ is termed ocean acidification (OA) [3]. The decrease in seawater $\mathrm{pH}$ is a consequence of changes in marine chemistry, where increased dissolved $\mathrm{CO}_{2}$ leads to increases in $\mathrm{H}_{2} \mathrm{CO}_{3}$ and hence to increases in $\mathrm{H}^{+}$and $\mathrm{HCO}_{3}{ }^{-}$concentrations and decreased $\mathrm{CO}_{3}{ }^{2-}$ concentration and $\mathrm{CaCO}_{3}$ saturation state. Changes in $\mathrm{pH}$ also affect biogeochemical processes such as alterations to trace metal speciation, which can have significant biological effects [4], [5].

If the photosynthesis of marine eukaryotic phytoplankton were supported solely by the diffusional supply of $\mathrm{CO}_{2}$ to the active site of the $\mathrm{CO}_{2}$ fixing enzyme Rubisco, then this process would be severely limited at the concentrations of $\mathrm{CO}_{2}$ currently found in seawater $(<10-30 \mu \mathrm{mol})$ [6]. However, most algae have been shown to be able to make extremely efficient use of low levels of dissolved inorganic carbon (DIC) by virtue of inducible carbon concentrating mechanisms (CGMs) [7]. The CGMs act to maintain internal $\mathrm{CO}_{2}$ concentrations higher than can be accounted for by diffusion-mediated entry of inorganic carbon.

CCM activity is down-regulated under high $\mathrm{CO}_{2}$; enhanced $\mathrm{CO}_{2}$ availability could thus reduce the energy cost for $\mathrm{CO}_{2}$ transport [8], and the re-allocation of energy may play a critical role in modulating primary production as well as elemental stoichiometry and species composition [6]. This, however, also may depend on other environmental factors. The effects of ocean acidification can have positive, neutral or negative aspects depending on the physiological processes involved, and may be species-specific [9]. While increased primary production under high $\mathrm{CO}_{2}$ has been found in many studies [10], energy loss due to enhanced respiration has also been reported under high $\mathrm{CO}_{2} /$ low $\mathrm{pH}$ conditions [11], possibly due to enhanced energy demand associated with the need to maintain intracellular acid-base stability [12]. The effects of ocean acidification are controversial with contradictory trends reported in the literature. While some of this could be due to species-specific responses it could also result from interactive effects with other environmental factors [13], [14].

Nutrient availability is well known to affect algal growth and production. This is especially so for nitrogen availability, which is seen in many cases as a major limiting factor for algal growth in the oceans [15]. Marine phytoplankton may experience increased nutrient limitation in the euphotic layer in the future due to 
intensified stratification in a warming ocean [16], [17]. Ocean acidification, at the same time, may affect ion and nutrient assimilation of algae either directly by altering proton or ion channels or indirectly by changes in chemical speciation and nutrient availability [18], [19]. Thus, ongoing ocean acidification together with intensified stratification could further decrease marine nutrient availability and uptake rates. Decreased nitrogen availability is expected to lead to decreased synthesis of chlorophyll and proteins in algae, which would have a strong influence on photosynthesis and physiological performance. Nitrogen limitation is known to affect carbon fixation because of potential impacts on levels of Rubisco and other proteins and also because nitrate assimilation is energy dependent and will compete with carbon fixation for ATP and reductant [20]. Thus changes in $\mathrm{C}$ and $\mathrm{N}$ acquisition may be reflected in altered cell carbon and nitrogen contents [21].

While the impacts of nutrient limitation under present day $\mathrm{CO}_{2}$ are well understood and there is an increasing literature on the effects of elevated $\mathrm{CO}_{2}$ on phytoplankton physiology and ecology (see reviews by Beardall et al., Riebesell and Tortell and references therein) [10], [22] and elemental ratios [23], most studies on the effects of ocean acidification have been carried out under nutrient replete conditions [11], [24] and there is very little information on interactive effects between nutrient limitation and elevated $\mathrm{CO}_{2}$ [10]. Since elevated $\mathrm{CO}_{2}$ and ocean acidification in a future world is likely to go hand-in-hand with a more restricted nutrient supply in the low- to mid-latitude open ocean, this is an important issue that needs addressing.

Thus, this paper considers how phytoplankton responses to ocean acidification may be affected by nitrogen limitation. Specifically, we have measured the cell size, growth, pigmentation, quantum yield, respiration, and CCM activity as well as cell carbon and nitrogen contents of Phaeodactylum tricornutum grown under high $\mathrm{CO}_{2}$ and low nitrogen conditions, to determine the possible interactive effects of ocean acidification and nitrogen limitation on this model diatom species.

\section{Materials and Methods}

\section{Statement of ethics}

The strain of the diatom Phaeodactylum tricornutum Bohlin (strain CGMA 106), originally isolated from the oligotrophic waters of the South China Sea in 2004, was obtained from the Center for Collections of Marine Bacteria and Phytoplankton (CGMBP) of the State Key Laboratory of Marine Environmental Sciences (Xiamen University). No specific permits were required for using this species.

\section{Algal culture conditions}

The diatom Phaeodactylum tricornutum Bohlin (strain CGMA 106) were grown in artificial seawater with Aquil medium enrichment [25] except that the $\mathrm{NO}_{3}{ }^{-}$concentration was adjusted to $110 \mu \mathrm{mol} \mathrm{L}{ }^{-1} \mathrm{NO}_{3}{ }^{-}(\mathrm{HN})$ or $10 \mu \mathrm{mol} \mathrm{L}{ }^{-1} \mathrm{NO}_{3}{ }^{-}(\mathrm{LN})$. The nitrogen-limiting level of $10 \mu \mathrm{M}$ was based on the surface inorganic nitrogen concentrations (unpublished) obtained from the oligotrophic South China Sea, ranging from 0 (undetectable) to $20 \mu \mathrm{M}$. Cultures were continuously aerated with ambient air of $390 \mu \mathrm{atm}$ of $\mathrm{CO}_{2}$ (LC) or with high $\mathrm{CO}_{2}$ of $1000 \mu \mathrm{atm}(\mathrm{HC})$ within plant $\mathrm{CO}_{2}$ chambers (HP1000G-D, Ruihua Instrument \& Equipment Co. Ltd, China) and bubbled at a constant flow rate of $300 \mathrm{ml} \mathrm{min}{ }^{-1}$. This allowed the following treatments, combining different $\mathrm{N}$ and $\mathrm{CO}_{2}$ levels, to be performed: LC-HN, LC-LN, HC-HN, HC-LN. The cells were grown semi-continuously at $20 \mathrm{C}$ under $70 \mu \mathrm{mol}$ photons $\mathrm{m}^{-2} \mathrm{~s}^{-1}$ illumination with a $12 \mathrm{~L}$ :
$12 \mathrm{D}$ photoperiod. Dilutions were carried out every $24 \mathrm{~h}$ to ensure cell concentrations did not exceed $3 \times 10^{5}$ cells $\mathrm{ml}^{-1}$ at their exponential growth phase so that $\mathrm{pH}$ change during growth at each $\mathrm{CO}_{2}$ level was less than 0.02 (Table 1). Cells were acclimated to each $\mathrm{NO}_{3}{ }^{-}$and $\mathrm{CO}_{2}$ combination for more than 10 generations before being used in the experiments described below.

The $\mathrm{pH}$ of cultures was measured daily, prior to dilution, with a pH probe (Mettler Toledo DL15 Titrator, Sweden), which was calibrated with standard NBS (National Bureau of Standards) buffer solutions (Hanna) at three $\mathrm{pH}$ points $(\mathrm{pH} 10.01, \mathrm{pH} 7.01$ and $\mathrm{pH} 4.01$ ). Measurement of dissolved inorganic carbon (DIC) was carried out using an automated system (AS-C3, Apollo Scitech), which was connected to an infrared gas detector (Li-Cor 7000, Li-Cor). Calculation of the carbonate system components $\left(\mathrm{HCO}_{3}{ }^{-}, \mathrm{CO}_{3}{ }^{2-}, \mathrm{CO}_{2}\right.$ and $\left.\mathrm{TA}\right)$ was carried out using known values of $\mathrm{DIC}, \mathrm{pH}$, nutrient concentration, salinity and temperature with a $\mathrm{CO}_{2}$ system analysis software (CO2SYS) [26] (Table 1). Carbonic acid dissociation constants $\left(\mathrm{K}_{1}\right.$ and $\left.\mathrm{K}_{2}\right)$ were according to Roy et al. [27], and that for boric acid $\left(\mathrm{K}_{\mathrm{B}}\right)$ was taken from Dickson [28].

\section{Growth rate and cell size measurements}

Cell numbers, mean cell volumes and size distributions were acquired with a Z2 ${ }^{\mathrm{TM}}$ Coulter Counter (Beckman, Buckinghamshire, UK). Determinations of growth rates were based on the cell number changes every $24 \mathrm{~h}$ and were calculated according to the equation: $\mu=\left(\ln \mathcal{N}_{1}-\ln \mathcal{N}_{0}\right) /\left(t_{1}-t_{0}\right)$, where $\mathcal{N}_{1}$ and $\mathcal{N}_{0}$ are the cell concentrations before dilution $\left(t_{1}\right)$ and after the previous dilution $\left(t_{0}\right)$ respectively. Growth rates were calculated based on measurements of 11-12 replicates for triplicate cultures under each $\mathrm{CO}_{2}$ level.

\section{Carotenoid and Chlorophyll measurements}

To determine the carotenoid and chlorophyll $a$ and $c$ contents of cells cultured in the different $\mathrm{CO}_{2}$ and $\mathrm{NO}_{3}{ }^{-}$conditions, cells were collected by filtration on to Whatman GF/F filters (pore size, $0.22 \mu \mathrm{m})$ and extracted overnight with absolute methanol at $4^{\circ} \mathrm{C}$. The extracts were then centrifuged for $10 \mathrm{~min}$ at $5000 \times \mathrm{g}$ and the absorbance of the supernatant was scanned with a spectrophotometer (DU800, Beckman, Fullerton, California, USA). Calculation of chlorophyll $a$ from the absorbance spectra followed the equation of Porra [29], chlorophyll $c$ was after Ritchie [30] and carotenoid was calculated according to Strickland and Parsons [31].

\section{Quantum yield measurements}

The quantum yield of cells grown in the different $\mathrm{CO}_{2}$ and $\mathrm{NO}_{3}{ }^{-}$conditions was measured with a XE-PAM (Walz, Germany) at both mid-light phase $\left(\mathrm{F}_{\mathrm{v}}, \mathrm{F}_{\mathrm{m}}{ }^{\prime}\right)$ and at the end of the dark phase $\left(\mathrm{F}_{\mathrm{v}} / \mathrm{F}_{\mathrm{m}}\right)$. The saturation light was set at $5000 \mu \mathrm{mol}$ photons $\mathrm{m}^{-2} \mathrm{~s}^{-1}$ for $0.8 \mathrm{~s}$.

\section{Determination of CCM activity from rETR vs DIC curves}

To estimate the affinity of cells for DIC (used as a proxy for CGM activity), cells cultured in different $\mathrm{CO}_{2}$ and $\mathrm{NO}_{3}{ }^{-}$ conditions were collected, washed with, and re-suspended into, DIC-free seawater with a $\mathrm{pH}$ of 8.20 . Cell densities after re-

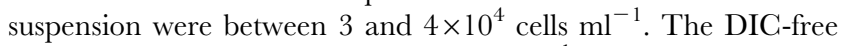
seawater was prepared by adding $1 \mathrm{~mol} \mathrm{~L}^{-1} \mathrm{HCl}$ to drop the $\mathrm{pH}$ below 3 and then bubbling with pure $\mathrm{N}_{2}$ for $1 \mathrm{~h}$. Tris-buffer was added to $20 \mathrm{mmol} \mathrm{L}^{-1}$ to adjust the $\mathrm{pH}$ back to 8.20 . Cells suspended in the DIC- free seawater were incubated at $150 \mu \mathrm{mol}$ $\mathrm{m}^{-2} \mathrm{~s}^{-1}$ for $15 \mathrm{~min}$ to exhaust any intracellular DIC, and 
Table 1. Chemical parameters of seawater carbonate system.

\begin{tabular}{|c|c|c|c|c|c|c|c|}
\hline & $\mathrm{pCO}_{2}$ & $\mathrm{pH}_{\mathrm{NBS}}$ & DIC & $\mathrm{HCO}_{3}{ }^{-}$ & $\mathrm{CO}_{3}{ }^{2-}$ & $\mathrm{CO}_{2}$ & TA \\
\hline & ( $\mu$ atm) & & $\left(\mu \mathrm{mol} \mathrm{Kg}{ }^{-1}\right)$ & $\left(\mu \mathrm{mol} \mathrm{Kg}{ }^{-1}\right)$ & $\left(\mu \mathrm{mol} \mathrm{Kg^{-1 }}\right)^{-}$ & $\left(\mu \mathrm{mol} \mathrm{Kg}{ }^{-1}\right)$ & $\left(\mu \mathrm{mol} \mathrm{Kg}{ }^{-1}\right)$ \\
\hline LC-HN & $416.6 \pm 15.4^{\mathrm{a}}$ & $8.17 \pm 0.02^{\mathrm{a}}$ & $2063.6 \pm 13.4^{\mathrm{a}}$ & $1851.1 \pm 12.0^{\mathrm{a}}$ & $199.1 \pm 6.7^{\mathrm{a}}$ & $13.1 \pm 0.1^{\mathrm{a}}$ & $2349.3 \pm 19.1^{\mathrm{a}}$ \\
\hline LC-LN & $404.0 \pm 11.9^{\mathrm{a}}$ & $8.18 \pm 0.01^{\mathrm{a}}$ & $2052.4 \pm 8.3^{\mathrm{a}}$ & $1837.2 \pm 5.8^{\mathrm{a}}$ & $202.2 \pm 5.8^{\mathrm{a}}$ & $13.1 \pm 0.4^{\mathrm{a}}$ & $2343.4 \pm 15.2^{\mathrm{a}}$ \\
\hline $\mathrm{HC}-\mathrm{HN}$ & $980.4 \pm 52.6^{b}$ & $7.85 \pm 0.02^{b}$ & $2209.7 \pm 19.3^{b}$ & $2072.0 \pm 20.8^{b}$ & $106.1 \pm 3.7^{b}$ & $30.9 \pm 1.0^{b}$ & $2341.4 \pm 14.1^{\mathrm{a}}$ \\
\hline HC-LN & $952.8 \pm 27.5^{b}$ & $7.86 \pm 0.01^{b}$ & $2200.8 \pm 11.5^{\mathrm{b}}$ & $2062.1 \pm 9.9^{b}$ & $108.0 \pm 3.4^{b}$ & $30.8 \pm 0.9^{b}$ & $2336.2 \pm 15.1^{\mathrm{a}}$ \\
\hline
\end{tabular}

Parameters of the seawater carbonate system under the ambient (390 $\mu \mathrm{atm}, \mathrm{LC})$ and elevated (1000 $\mu$ atm, $\mathrm{HC}) \mathrm{CO}_{2}$ concentrations as well as nitrogen-replete $(\mathrm{HN})$ and limited (LN) conditions before the partial renewal of the medium for the semi-continuous cultures. Total inorganic carbon (DIC), pH, salinity, nutrient concentration and temperature were used to derive all other parameters using the $\mathrm{CO}_{2}$ system analyzing software CO2SYS [36]. Data are the means \pm SD of 4 measurements. Different letters indicate significant differences among the treatments at the $\mathrm{P}<0.05$ level.

doi:10.1371/journal.pone.0051590.t001

$\mathrm{NaHCO}_{3}$ solution was then added into each vial of algal suspension to obtain different DIC concentrations. After further incubation under a photon flux of $70 \mu \mathrm{mol} \mathrm{m} \mathrm{m}^{-2} \mathrm{~s}^{-1}$ for $10 \mathrm{~min}$ (less than $0.1 \%$ DIC was consumed), a rapid light curve was determined with the XE-PAM, and the resulting data fitted with the equation of Eilers and Peeters [32]: $y=x /\left(a x^{2}+b x+c\right)$, where $a$, $\mathrm{b}, \mathrm{c}$ are estimated parameters, $\mathrm{x}$ photon flux density, and $\mathrm{y}$ the rETR value. Light saturated rates of electron transport $\left(\mathrm{rETR}_{\max }\right)$ at the different DIC concentrations can be calculated from the fitted rapid light curve: $\mathrm{rETR}_{\max }=1 /\left[\mathrm{b}+2(\mathrm{ac})^{1 / 2}\right]$, and the light harvesting efficiency $(\alpha)$ was calculated with the equation: $\alpha=1 / \mathrm{c}$. To quantify the relationship between EETR $_{\max }$ and DIC concentrations, we fitted the two parameters using the Michaelis-Menten equation to determine light- and DIC-saturated rates of photosynthesis and the half-saturation constant $\mathrm{K}_{1 / 2}$ DIC and $\mathrm{K}_{1 / 2}$ $\mathrm{CO} 2$ for DIC-dependent electron transport.

\section{Dark respiration measurements}

Cells were gently filtered on to polycarbonate membrane filters (0.22 $\mu \mathrm{m}, \mathrm{Q} / \mathrm{YY} 8-1-88, \mathrm{Xinya}$, China) with a vacuum pump at a pressure of less than $0.02 \mathrm{~Pa}$. to ensure cells were intact, based on a microscopic checkup, and were then re-suspended into $20 \mathrm{mmol}$ $\mathrm{L}^{-1}$ Tris-buffered media of the respective composition (LC-HN, LC-LN, HC-HN and HC-LN). Each treatment had a known cell

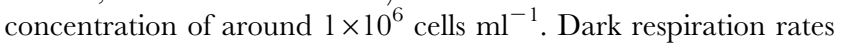
were determined with a Clark type oxygen electrode (5300A, YSI) from changes in oxygen concentration over time at $20^{\circ} \mathrm{C}$. A twopoint calibration (seawater bubbled with air until equilibrium saturation and $\mathrm{O}_{2}$ deprivation with excess sodium sulfite as zero oxygen) was carried out before respiration measurements. The possible contribution of bacterial respiration was tested on the culture filtrate that passed through a filter pore size of $1 \mu \mathrm{m}$ (mixed cellulose lipid membranes), which would not exclude the few bacteria present, and there was no detectable bacterial $\mathrm{O}_{2}$ consumption.

\section{Measurement of carbon and nitrogen contents}

To determine particulate organic carbon (POC) and nitrogen $(\mathrm{PON})$ in Phaeodactylum tricornutum grown under different $\mathrm{CO}_{2}$ and $\mathrm{NO}_{3}{ }^{-}$concentrations, cells were collected in the mid-light period by filtration onto pre-combusted $\left(450^{\circ} \mathrm{C}, 6 \mathrm{~h}\right) \mathrm{GF} / \mathrm{F}$ filters (Whatman). Filters were acidified with $0.1 \mathrm{~N} \mathrm{HCl}$ fumes for $12 \mathrm{~h}$ and then dried overnight in an oven at $60^{\circ} \mathrm{C}$. Carbon and nitrogen contents were determined with a PerkinElmer Series II CHNS/O Analyzer 2400.

\section{Statistical analysis}

One-way analysis of variance (ANOVA) and Tukey's test were used to establish differences among treatments at a confidence level of $95 \%$. Interactive effects between $\mathrm{CO}_{2}$ and $\mathrm{NO}_{3}{ }^{-}$were analyzed using a Tukey post hoc test.

\section{Results}

\section{Growth rate}

Growth rates were inhibited under nitrogen limited conditions under both LC $(30 \%, P<0.001)$ and $\mathrm{HC}(38 \%, P<0.001)$ conditions (Figure 1). No direct effects on growth rate were found between the $\mathrm{CO}_{2}$ treatments (nitrogen replete, $P=0.24$; nitrogen limited, $P=0.72$ ). No interactive effect was found between $\mathrm{CO}_{2}$ and $\mathrm{NO}_{3}{ }^{-}$levels $(P=0.3)$.

\section{Chlorophyll and carotenoid contents}

The effects of nitrogen and $\mathrm{CO}_{2}$ treatments on cellular chlorophyll and carotenoid concentrations showed the same trend as cell size and growth rate. Nitrogen limitation decreased the carotenoid, chlorophyll $a$ and $c$ contents by $50 \%$ and $62 \%$ (Figure 2A), 48\% and 60\% (Figure 2B), 45\% and 63\% (Figure 2C) in the LC and HC groups, respectively $(P<0.05)$. No direct effects

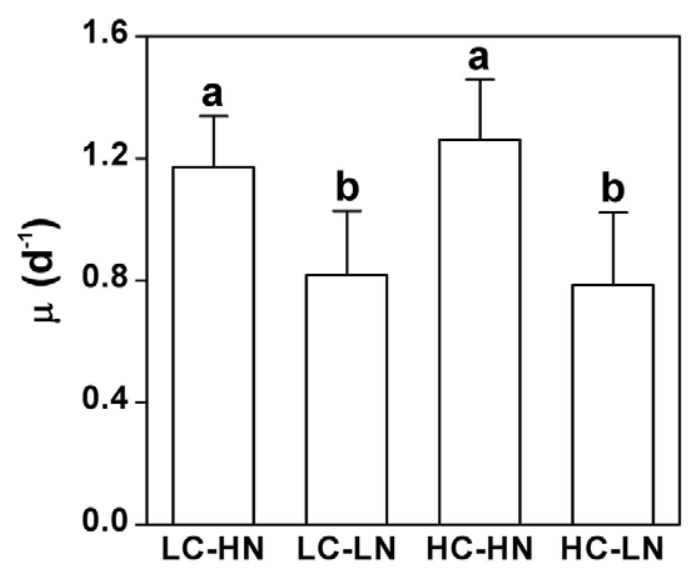

Figure 1. Specific growth rates of $P$. tricornutum. The growth rates were measured after cells acclimated for 10 generations under nitrogen limited (LN) and replete (HN) levels in $390(\mathrm{LC})$ and $1000 \mu \mathrm{atm}(\mathrm{HC}) \mathrm{CO}_{2}$ conditions. The different letters indicate significant differences among the treatments at the $P<0.05$ level. Vertical bars are means $\pm S D$, $\mathrm{n}=11-12$.

doi:10.1371/journal.pone.0051590.g001 
on pigmentation were found between the $\mathrm{CO}_{2}$ treatments $(P>0.05)$. The ratio of chlorophyll $a$ to carotenoids showed no significant difference among the treatments $(P>0.05)$ (Figure 2D). No interactive effects on chlorophyll $a(P=0.086), c(P=0.133)$, carotenoid $(P=0.475)$ and the ratio of chlorophyll $a$ to carotenoids $(P=0.657)$ were found between $\mathrm{CO}_{2}$ and $\mathrm{NO}_{3}{ }^{-}$levels.

\section{Quantum yield}

Maximum quantum yields $\left(\mathrm{F}_{\mathrm{v}} / \mathrm{F}_{\mathrm{m}}\right)$, measured at the end of the dark period, showed no significant differences among treatments $(P>0.05)$ (Figure 3A). However, in the mid-light period, cells cultured under nitrogen limited conditions showed decreases in effective quantum yield $\left(\mathrm{F}_{\mathrm{v}}{ }^{\prime} / \mathrm{F}_{\mathrm{m}}{ }^{\prime}\right)$ by $12 \%$ and $15 \%$ in the $\mathrm{LC}$ $(P=0.01)$ and HC $(P=0.002)$ treatments respectively, compared to those under nitrogen replete conditions (Figure $3 \mathrm{~B}$ ). No significant (nitrogen replete, $P=0.43$; nitrogen limited, $P=0.91$ ) change in the yield was found between the low and high $\mathrm{CO}_{2}$ levels (Figure 3A, B). No interactive effect on yield was found between $\mathrm{CO}_{2}$ and $\mathrm{NO}_{3}{ }^{-}$levels $\left(\mathrm{F}_{\mathrm{v}} / \mathrm{F}_{\mathrm{m}}, \quad P=0.24 ; \mathrm{F}_{\mathrm{v}}{ }^{\prime} / \mathrm{F}_{\mathrm{m}}\right.$ ', $P=0.58)$.

\section{Cell size}

Increased dissolved $\mathrm{CO}_{2}$ concentration did not affect the mean cell size (as Effective Spherical Diameter) and cell volume of Phaeodactylum tricornutum under nitrogen replete conditions. However, nitrogen limitation did cause significant $(P<0.001)$ decreases in cell size and cell volume (Figure 4,5$)$. Mean cell volumes were 65.3 and $67.6 \mu \mathrm{m}^{3}$ in $\mathrm{LC}$ and $\mathrm{HC}$ treatments, and nitrogen limitation significantly decreased these values to 43.0 and $41.3 \mu^{3}$ (by $34 \%$ and $39 \%$ ), respectively $(P<0.001)$ (Figure 5A). Mean cell sizes (as Effective Spherical Diameter) in LC and HC were $4.91 \pm 0.08$ and $4.95 \pm 0.00 \mu \mathrm{m}$ respectively, under nitrogen replete conditions (Figure 5B). Under nitrogen limitation, cell size decreased by $13 \%$ and $15 \%(P<0.001)$, to $4.25 \pm 0.02 \mu \mathrm{m}$ and $4.19 \pm 0.01 \mu \mathrm{m}$ in LC and HC cells, respectively (Figure $5 \mathrm{~B}$ ). No significant differences in both cell size $(P=0.56)$ and volume $(P=0.39)$ were found between low and high $\mathrm{CO}_{2}$ levels under the nitrogen replete conditions. However, high $\mathrm{CO}_{2}$ cells showed a small but significant decrease of both cell size $(P=0.02)$ and

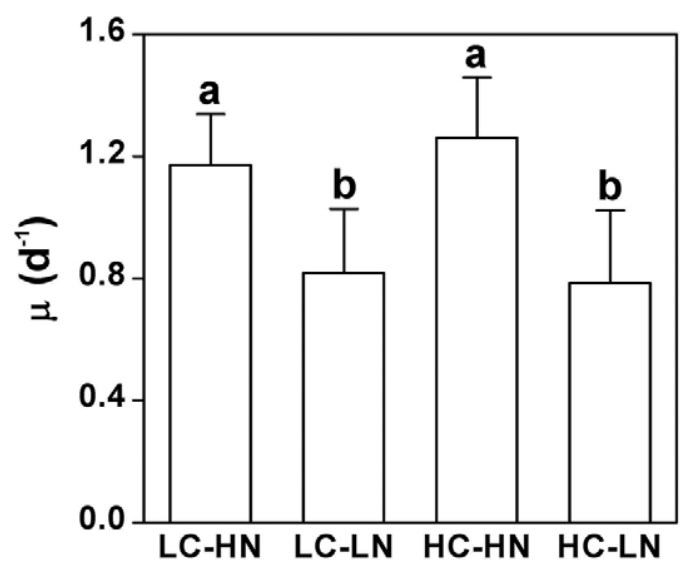

Figure 2. Pigments of $\boldsymbol{P}$. tricornutum. (a) Carotenoid, (b) $\mathrm{chl} a_{\text {, }}$ (c) chl $c$ contents and (d) ratio of chl a to carotenoid of Phaeodactylum tricornutum grown at nitrogen limited $(\mathrm{LN})$ and replete $(\mathrm{HN})$ levels in 390 (LC) and $1000 \mu \mathrm{atm}$ ( $\mathrm{HC}) \mathrm{CO}_{2}$ conditions, measured after the cells had acclimated for 10 generations. The different letters indicate significant differences among the treatments at the $P<0.05$ level. Vertical bars are means $\pm S D, n=9-13$. doi:10.1371/journal.pone.0051590.g002
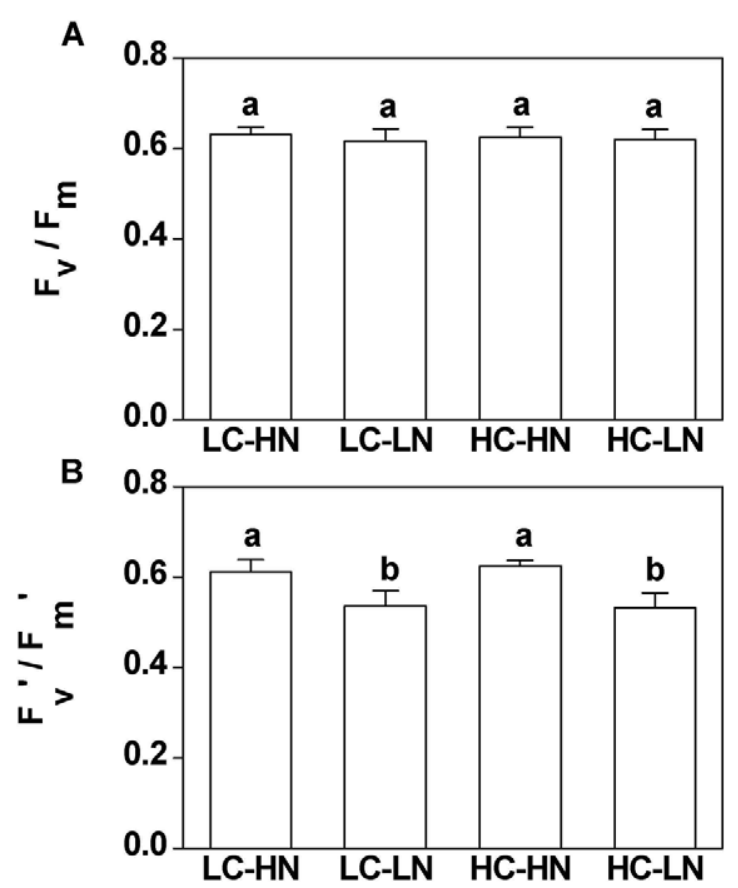

Figure 3. Photochemical quantum yield of $P$. tricornutum. (a) The maximal $\left(\mathrm{F}_{\mathrm{v}} / \mathrm{F}_{\mathrm{m}}\right)$ and (b) effective $\left(\mathrm{F}_{\mathrm{v}}{ }^{\prime} / \mathrm{F}_{\mathrm{m}}{ }^{\prime}\right)$ quantum yield of $P$. tricornutum cells grown in LC-HN, LC-LN, HC-HN and HC-LN conditions, measured after the cells had acclimated for 10 generations. The different letters indicate significant differences between treatments at the $P<0.05$ level. Vertical bars are means \pm SD, $n=3-5$.

doi:10.1371/journal.pone.0051590.g003

volume $(P=0.04)$ when nitrogen was limited. No interactive effects were found between $\mathrm{CO}_{2}$ and $\mathrm{NO}_{3}{ }^{-}$levels in both cell size $(P=0.16)$ and cell volume $(P=0.14)$.

\section{$P$ vs DIC characteristics}

With increasing DIC concentration in the medium, high $\mathrm{CO}_{2}$, $\mathrm{N}$-replete cultures had a significantly $(\mathrm{p}=0.04)$ elevated $\mathrm{rETR}_{\max }$ (light and DIC-saturated rate of electron transfer) compared to low $\mathrm{CO}_{2}$, N-replete cells $\left(\mathrm{rETR}_{\max }\right.$ values were HC-HN 110.08 \pm 5.78 , LC-HN 97.47 \pm 4.55$)$. The $\mathrm{rETR}_{\max }$ under N-limited conditions was not affected by the $\mathrm{CO}_{2}$ level (LC-LN $(\mathrm{n}=2)$ 93.24 2 2.12, HC-LN (n=2) 98.31 $\pm 7.99 ; \quad P=0.48$ ) (Figure 6A, B). The calculated $\mathrm{K}_{1 / 2}$ DIC values indicate that CGM activity was down-regulated under $\mathrm{HC}$ conditions $(P=0.04)$, with $\mathrm{K}_{1 / 2}$ DIC values in the high $\mathrm{N}$-grown cells increasing from 57.0 (LC-HN) to 103.4 $\mu \mathrm{mol} \mathrm{L}{ }^{-1}(\mathrm{HC}-\mathrm{HN})$. N-limitation also caused a rise in $\mathrm{K}_{1 / 2}$ DIC to $110.4 \mu \mathrm{mol} \mathrm{L}^{-1}$ even under low $\mathrm{CO}_{2}$, and this increased to $134.2 \mu \mathrm{mol} \mathrm{L}{ }^{-1}$ in HC-LN cells (Figure $6 \mathrm{C}$ ). The $\mathrm{K}_{1 / 2 \mathrm{CO} 2}$ shows the same trend as $\mathrm{K}_{1 / 2}$ DIC and values were $0.34,0.66,0.62$ and $0.81 \mu \mathrm{mol} \mathrm{L}{ }^{-1}$ in the LC-HN, LC-LN, HC-HN and HC-LN treatments respectively. The light harvesting efficiency $(\alpha)$ of the cells, derived from RLC at different DIC levels, was not affected $(P=0.12)$ by $\mathrm{CO}_{2}$ levels when nitrogen was limited, but was significantly $(P=0.01)$ elevated by the $\mathrm{CO}_{2}$ enrichment in $\mathrm{N}$ replete conditions at a DIC level of $138 \mu \mathrm{mol} \mathrm{L}^{-1}$. Such a trend was still observed at $275 \mu \mathrm{mol} \mathrm{L}{ }^{-1}$, although with the differences being statistically insignificant (nitrogen replete, $P=0.35$; nitrogen limited, $P=0.32$ ) (Figure 7). At the ambient DIC level of $2200 \mu \mathrm{mol} \mathrm{L} \mathrm{L}^{-1}$, no significant difference (nitrogen replete, $P=0.22$; nitrogen limited, $P=0.23$ ) in light harvesting efficiency was found among the treatments (Figure 7). 
A

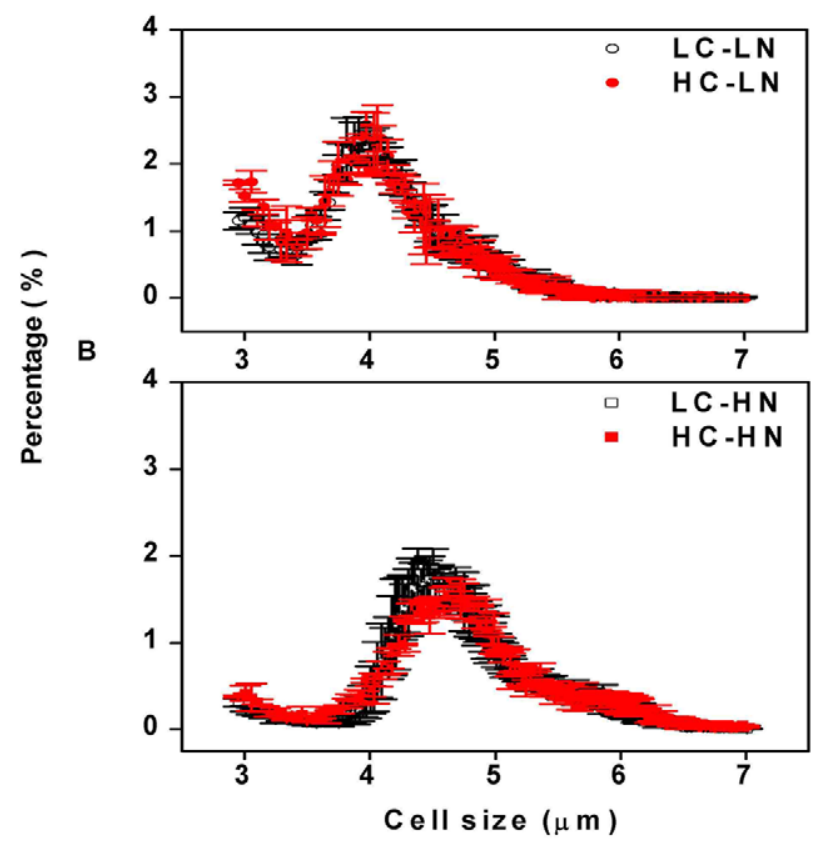

Figure 4. Cell sizes of $\boldsymbol{P}$. tricornutum. The cells grown at (a) N-limited (LN) and (b) N-replete (HN) conditions with 390 and $1000 \mu$ atm $\mathrm{CO}_{2}$, measured after the cells had acclimated for 10 generations. Vertical bars are means $\pm S D, n=2-4$.

doi:10.1371/journal.pone.0051590.g004

\section{Dark respiration rates}

Cells grown under nitrogen limitation, irrespective of $\mathrm{CO}_{2}$ level, showed approximately a doubling in respiration rate, compared to ambient $\mathrm{CO}_{2}$, nitrogen replete cells. With N-replete cells, high $\mathrm{CO}_{2}$ also resulted in an increase in cellular respiration rates (Figure 7A). When dark respiration was expressed on a per chlorophyll $a$ basis, rates were enhanced by $298 \%, 110 \%$ and $305 \%$ in LC-LN, HC-HN, HC-LN treatments respectively, compared to the LC-HN conditions (Figure 7B). No interactive effects on dark respiration were found between $\mathrm{CO}_{2}$ and $\mathrm{NO}_{3}{ }^{-}$ levels $(P=0.16)$.

\section{Carbon and nitrogen contents}

Nitrogen limitation significantly decreased the nitrogen content of cells cultured in both LC (by ca. 32\%) and HC (by ca. 28\%) conditions compared with the nitrogen-replete treatments $(P<0.001)$ (Table 2). Nitrogen limitation led to an increase in the $\mathrm{C}: \mathrm{N}$ ratio by $21 \%$ in the $\mathrm{LC}$ condition, and this enhancement increased to $45 \%$ in the $\mathrm{HC}$ condition $(P<0.001)$. However, under the nitrogen replete treatment the $\mathrm{CO}_{2}$ concentration did not affect the $\mathrm{C}: \mathrm{N}$ ratio $(P=0.24)$, even though the cells at the high $\mathrm{CO}_{2}$ level significantly increased their nitrogen content by $13 \%$ $(P=0.04)$. Turkey's post hoc test showed that there were significant interactive effects on $\mathrm{C}: \mathrm{N}$ found between $\mathrm{CO}_{2}$ and $\mathrm{NO}_{3}{ }^{-}$levels $(P<0.001)$.

\section{Discussion}

While the elevated $\mathrm{CO}_{2}$ concentration of $1000 \mu \mathrm{atm}$ did not cause significant differences in growth, pigment contents, effective quantum yield and cell size, nitrogen limitation decreased all these parameters in the diatom Phaeodactylum tricormutum (Figures 1, 2, 3, 4). Both the elevation of $\mathrm{CO}_{2}$ and N-limitation led to a down-

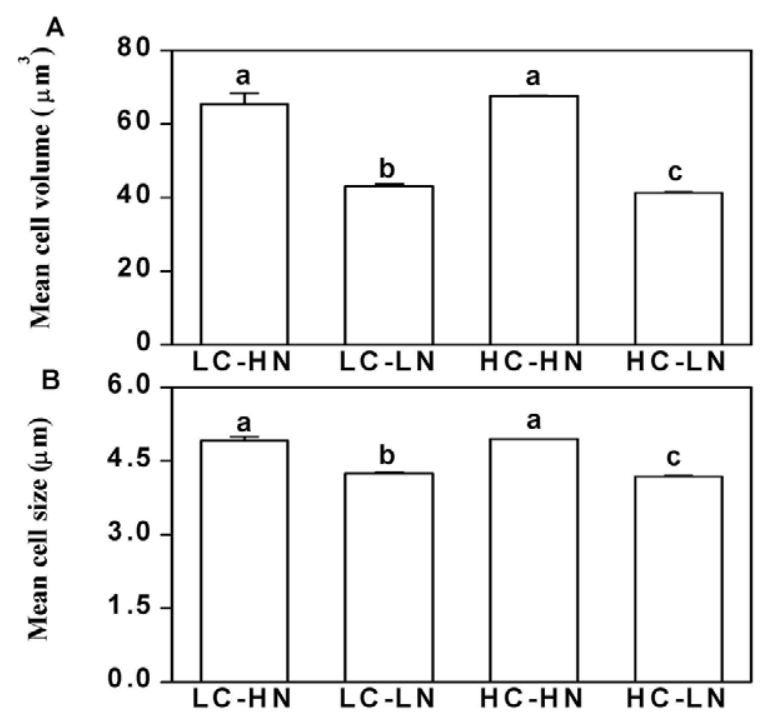

Figure 5. Mean cell volume and size of $\boldsymbol{P}$. tricornutum. (a) Mean cell volume and (b) cell size of Phaeodactylum tricornutum cultured under N-limited and N-replete conditions with 390 and $1000 \mu$ atm $\mathrm{CO}_{2}$, measured after the cells had acclimated for 10 generations. Vertical bars are means $\pm S D, n=2-4$.

doi:10.1371/journal.pone.0051590.g005

regulation of $\mathrm{CO}_{2}$ concentrating mechanism (CGM) activity, as reflected in the increased/decreased $\mathrm{K}_{1 / 2}$ DIC or $\mathrm{K}_{1 / 2} \mathrm{CO} 2 . \mathrm{N}$ limitation and increased $\mathrm{pCO}_{2} /$ reduced $\mathrm{pH}$ led to the lowest light use efficiency under Ci-limited conditions (Figure 7), with this trend effect being minimized under elevated levels of DIC. Ocean acidification increased dark respiration under $\mathrm{N}$-limited conditions
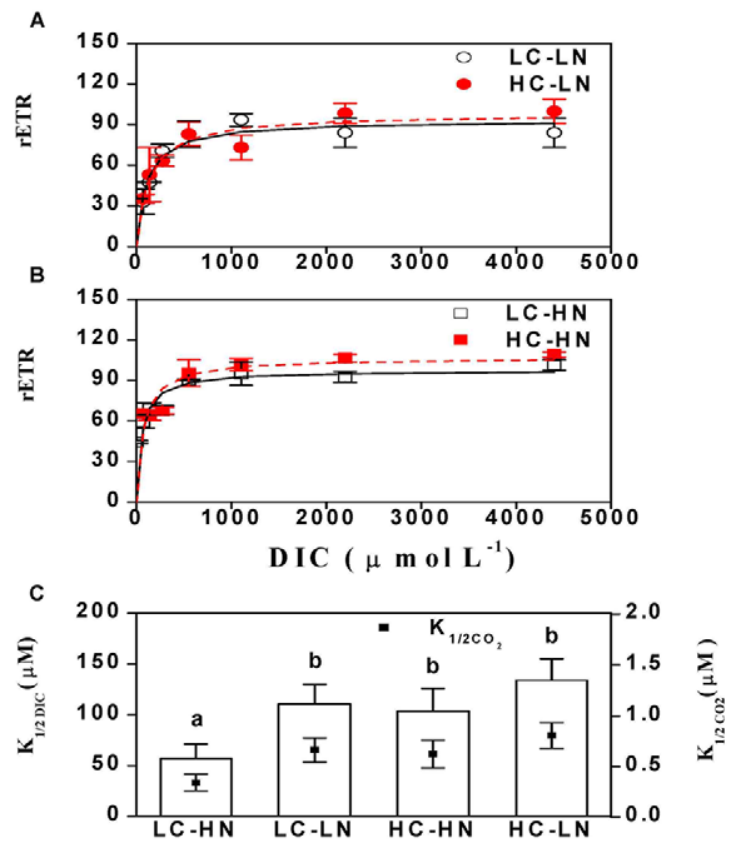

Figure 6. Photosynthetic electron transfer rate, $K_{1 / 2}$ DIC or $K_{1 / 2}$ $\mathrm{CO}$ of $P$. tricornutum. Photosynthetic electron transfer rate of the cells cultured in (a) HC-HN, HC-LN and (b) LC-HN and LC-LN when measured at different DIC concentrations. (c) $\mathrm{K}_{1 / 2} \mathrm{DIC}$ or $\mathrm{K}_{1 / 2}$ CO2 values were calculated from (a) and (b). The different letters indicate significant differences between treatments at the $P<0.05$ level. Vertical bars are means $\pm S D, n=3$ (except LC-LN and HC-LN were 2 replicates). doi:10.1371/journal.pone.0051590.g006 


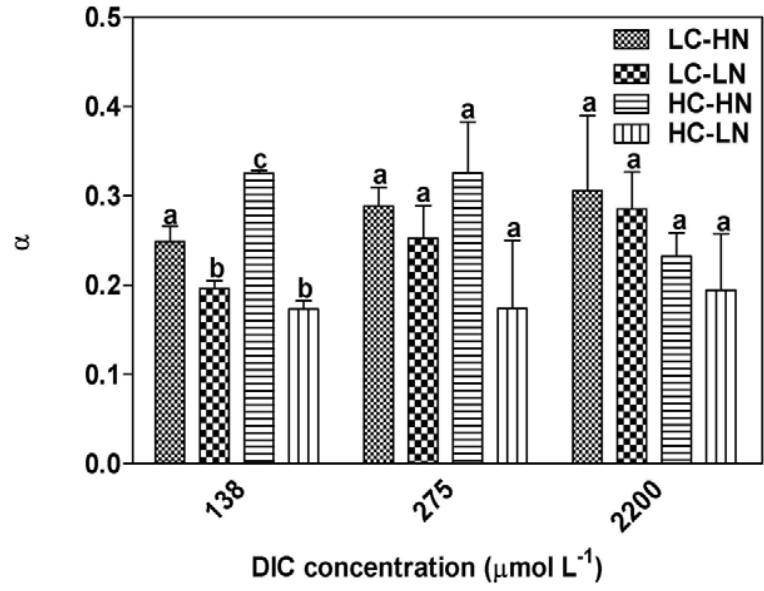

Figure 7. The apparent light use efficiency of $P$. tricornutum. The apparent light use efficiency of the cells cultured in LC-HN, LC-LN, HC$\mathrm{HN}$ and HC-LN, when measured at DIC-limited or ambient levels. The different letters indicate significant differences among the treatments at the $P<0.05$ level. Vertical bars are means $\pm S D, n=3$ (except LC-LN and HC-LN were 2 replicates).

doi:10.1371/journal.pone.0051590.g007

(Figure 8). The high $\mathrm{CO}_{2}$ and low nitrate combination altered the cells' elemental stoichiometry, with the C:N ratio increased by $45 \%$ compared to the low $\mathrm{CO}_{2}$ and nitrate replete grown cells (Table 2).

\section{Basic cell parameters}

Confirming previous studies on growth of diatoms, including $P$. tricornutum, under elevated $\mathrm{CO}_{2}$ [33], [34], growth at the elevated $\mathrm{CO}_{2}$ levels that are expected by the end of the century did not cause a significant increase in growth rate. This was the case regardless whether the organism was grown under $\mathrm{N}$ depletion or $\mathrm{N}$ repleted conditions. Earlier studies in our laboratory on the same species showed an enhanced growth rate (ca. 5\%) under elevated $\mathrm{CO}_{2}$ and a PAR of $120 \mu \mathrm{mol} \mathrm{m} \mathrm{m}^{-2} \mathrm{~s}^{-1}$ [11]. In the current study we did not find improved growth under a PAR level of $70 \mu \mathrm{mol} \mathrm{m} \mathrm{m}^{-2} \mathrm{~s}^{-1}$. Recently, changes in light levels have recently been shown to mediate diatoms' responses to ocean acidification [14]. Even although both light levels are subsaturating for photosynthesis, less photosynthetic carbon fixation under $70 \mu \mathrm{mol} \mathrm{m} \mathrm{s}^{-2} \mathrm{~s}^{-1}$ should have resulted in less or no growth stimulation due to the enhanced respiratory carbon loss (Figure 8).

Although growth rates were clearly limited by a decrease in Nsupply and, as has commonly been reported [35], chlorophyll levels were significantly decreased in N-limited cells, there was no change in the chl:carotenoid ratio, sometimes used as an indicator for N-limitation [35], under our experimental conditions (Figure 2). A lack of effect of $\mathrm{CO}_{2}$ levels on cellular pigment content is consistent with previous data on diatoms [11], [36] and other microalgae [37]. Furthermore, dark-adapted maximal quantum yield showed no decrease in N-limited cells, although the effective quantum yield show a small, but significant drop; neither parameter was affected by growth at elevated $\mathrm{CO}_{2}$ (Figure 3). Previous studies on a green alga Ulva rigida showed that both $\mathrm{F}_{\mathrm{v}}$ / $\mathrm{F}_{\mathrm{m}}$ and $\mathrm{F}_{\mathrm{v}}{ }^{\prime} / \mathrm{F}_{\mathrm{m}}$ ' were significantly down-regulated by high $\mathrm{CO}_{2}$, and that nitrogen limitation further decreased both parameters [38]. A decline in $\mathrm{F}_{\mathrm{v}} / \mathrm{F}_{\mathrm{m}}$ is a general response to nitrogen limitation [39]. There is a possibility that the urea cycle found in Phaeodactylum functions to support the photosynthetic machinery by recycling $\mathrm{N}$ under the $\mathrm{N}$-limited conditions [40]. In the light
Table 2. Elemental stoichiometry of organic carbon and nitrogen contents and their ratios in Phaeodactylum tricornutum.

\begin{tabular}{|c|c|c|c|}
\hline & $C\left(\right.$ pg cell $\left.{ }^{-1}\right)$ & $N\left(\right.$ pg cell $\left.{ }^{-1}\right)$ & $\mathrm{C} / \mathrm{N}(\mathrm{mol} / \mathrm{mol})$ \\
\hline LC-HN & $8.00 \pm 1.16^{a}$ & $1.69 \pm 0.26^{a}$ & $5.53 \pm 0.35^{a}$ \\
\hline LC-LN & $6.55 \pm 0.52^{b}$ & $1.15 \pm 0.13^{b}$ & $6.71 \pm 0.60^{b}$ \\
\hline $\mathrm{HC}-\mathrm{HN}$ & $8.58 \pm 0.91^{\text {ac }}$ & $1.91 \pm 0.13^{c}$ & $5.26 \pm 0.56^{a}$ \\
\hline HC-LN & $9.29 \pm 0.82^{c}$ & $1.37 \pm 0.24^{d}$ & $8.02 \pm 0.69^{c}$ \\
\hline
\end{tabular}

The particulate organic carbon (POC), particulate organic nitrogen (PON) and molar ratio of POC to PON of Phaeodactylum tricornutum when grown in LC $(390 \mu \mathrm{atm}, \mathrm{LC})$ and $\mathrm{HC}(1000 \mu \mathrm{atm}, \mathrm{HC})$ under $\mathrm{NO}_{3}{ }^{-}$replete $(\mathrm{HN})$ and limited (LN) conditions. Data are the means \pm SD of 8 to 12 measurements. The superscripts of lowercase letters represent significant differences $(P<0.05)$ between treatments.

doi:10.1371/journal.pone.0051590.t002

period, in contrast, carbon fixation and nitrogen acquisition are both competing for energy [20], thereby leading to lower yield under the $\mathrm{N}$-limited conditions.

Cell size was significantly smaller by ca. $15 \%$ in N-limited cells, a phenomenon that has been reported for dinoflagellates and for the coccolithophore, Emiliania huxleyi [41], [42], [43]. Considering the lower specific growth rate and increased C:N ratio under future high $\mathrm{CO}_{2}$ and low nutrient conditions (Table 2), the diatoms' carbon fixation efficiency per unit nitrogen will increase in the surface seawater.

\section{Photosynthesis vs DIC characteristics}

Elevated $\mathrm{CO}_{2}$ caused a slight increase in photosynthetic capacity (measured as rETR $_{\max }$ under light and DIC-saturated conditions) under $\mathrm{N}$-replete, but not under N-limited conditions (Figure 6). Small increases in the DIC-saturated photosynthetic capacity of diatoms grown under elevated $\mathrm{CO}_{2}$ have been reported previously [11], [36], [44]. Growth under N-limited conditions caused an increase in $\mathrm{K}_{1 / 2}$ DIC in low- $\mathrm{CO}_{2}$ grown cells.

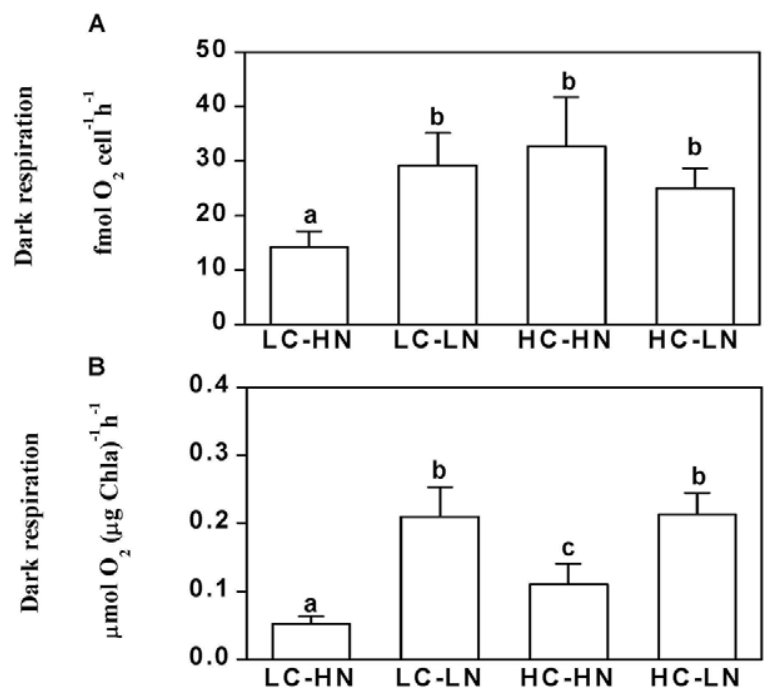

Figure 8. Dark respiration rates of $P$. tricornutum. Dark respiration rates (a) per cell or (b) per chl $a$ cultured in LC-HN, LC-LN, HC-HN and HC-LN grown cells. The different letters above the bars indicate significant differences among the treatments at the $P<0.05$ level. Vertical bars are means $\pm S D$, except the HC-LN treatments that had 2 replicates, all other data are from 4 replicates.

doi:10.1371/journal.pone.0051590.g008 
This indicates a down-regulation of CGM activity by nitrogen limitation. This is in contrast to the reports of Young and Beardall for the green alga Dunaliaella tertiolecta showing cells grown under low $\mathrm{CO}_{2}$ exhibited increasing affinity (lower $\mathrm{K}_{1 / 2}$ DIC) for DIC under N-limited growth and work on Chlorella emersonii in which cells under $5 \% \mathrm{CO}_{2}$ showed partial induction of CCM activity when N-limited [45], [46]. Such responses have been viewed as a way of improving N-use efficiency and maintaining Rubisco activity with less Rubisco protein when resources such as nitrogen are in short supply [45]. However, induction of CGM activity under N-limitation does not always occur, especially when cells are grown under low $\mathrm{CO}_{2}$ or are not severely $\mathrm{N}$-limited (see Table 1) [39], [47]. In P. tricornutum, nitrogen storage strategy using the urea cycle could mediate the diatom's CCM to decrease the influence of elevated $\mathrm{CO}_{2}$ levels [40].

The changes in $\mathrm{rETR}_{\max }$ under elevated $\mathrm{CO}_{2}$ and N-replete conditions may be partially negated by the rise in dark respiration and contribute to the lack of effect of high $\mathrm{CO}_{2}$ on growth rate. However, low $\mathrm{CO}_{2}$ grown cells that were N-limited also exhibited higher respiration rates, contributing to the lower growth rates found in N-limited cells. Growth at elevated $\mathrm{CO}_{2}$ exposes cells to a lower $\mathrm{pH}$, which might impose additional energetic costs for acidbase regulation to sustain metabolic integrity [48]. Metabolic processes also influence the $\mathrm{pH}$ in the immediate proximity to the cell surface [49], and under low N levels (here supplied as nitrate), the near cell $\mathrm{pH}$ would become less alkaline $\left(\mathrm{NO}_{3}{ }^{-}\right.$uptake leads to $\mathrm{OH}^{-}$extrusion), again leading to increased energy demand to maintain $\mathrm{pH}$ gradients across the cell membrane.

\section{Elemental composition}

The elemental composition and macromolecular composition of phytoplankton is critically important for secondary producers such as copepods, fish and shrimp, and food nutritional quality influences energy flow through marine food chains [50]. Recently Rossoll et al. found that the fatty acid composition of the diatom Thalassiosira pseudonana cultured at elevated $\mathrm{CO}_{2}$ was altered and that this significantly affected the growth and egg production of a copepod, Acartia tonsa [51]. Riebesell et al. reported an increased C:N ratio in a mesocosm study dominated by diatoms [52], whereas Burkhardt et al. reported both increases and decreases in $\mathrm{C}: \mathrm{N}$ ratio with increasing $\mathrm{CO}_{2}$, dependent on the species [23]. In our study, nitrogen limitation decreased both the carbon and

\section{References}

1. Sabine CL, Feely RA, Gruber N, Key RM, Lee K, et al. (2004) The oceanic sink for anthropogenic $\mathrm{CO}_{2}$. Science 305: 367-371.

2. IPCC (2001) Climate change 2001: the scientific basis. Contribution of Working Group I to the Third Assessment Report of the Intergovernmental Panel on Climate Change. Cambridge University Press, Cambridge, United Kingdom and New York, NY, USA. 881 p.

3. Doney SC, Fabry VJ, Feely RA, Kleypas JA (2009) Ocean acidification: The other $\mathrm{CO}_{2}$ problem. Annu Rev Marine Sci 1: 169-192.

4. Caldeira K, Wickett ME (2003) Anthropogenic carbon and ocean pH. Nature 425: 365-365.

5. Millero FJ, Woosley R, Ditrolio B, Waters J (2009) Effect of ocean acidification on the speciation of metals in seawater. Oceanography 22: 72-85.

6. Reinfelder JR (2011) Carbon concentrating mechanisms in eukaryotic marine phytoplankton. Annu Rev Marine Sci 3: 291-315.

7. Raven JA, Giordano M, Beardall J, Maberly SC (2011) Algal and aquatic plant carbon concentrating mechanisms in relation to environmental change. Photosynth Res 109: 281-296.

8. Hopkinson BM, Dupont CL, Allen AE, Morel FMM (2011) Efficiency of the $\mathrm{CO}_{2}$-concentrating mechanism of diatoms. Proc Natl Acad Sci 108: 3830-3837.

9. Gao K (2011) Positive and negative effects of ocean acidification: Physiological responses of algae. Journal of Xiamen University (Natural Science) 50: 411-417. (In Chinese)

10. Riebesell U, Tortell PD (2011) Effects of ocean acidification on pelagic organisms and ecosystems. In: Gattuso J-P, Hansson L, editors. Ocean acidification. New York: Oxford University Press. 99-116. nitrogen contents per cell but these changes were not parallel and led to an enhanced $\mathrm{C}: \mathrm{N}$ ratio in both $\mathrm{LC}$ and $\mathrm{HC}$ conditions. Cells cultured under high $\mathrm{CO}_{2}$ showed increased cell quotas for both carbon and nitrogen, irrespective of nitrogen supply (Table 2). The highest $\mathrm{C}: \mathrm{N}$ was found in the high $\mathrm{CO}_{2}$ /low nitrogen conditions that are expected to dominate the open ocean in the near future, indicating that these synergistic effects of ocean acidification and nitrogen limitation could decrease the food quality of marine phytoplankton.

Although increased marine dissolved $\mathrm{CO}_{2}$ may bring some benefits in terms of improved carbon supply to some phytoplankton [8], these organisms also face an extra cost associated with changed marine chemistry, especially $\mathrm{pH}$ stress, which could also lead to more energetic constraints on growth. Thus, the net benefit of higher $\mathrm{CO}_{2}$ will be a balance between gains and losses determined by the various environmental factors associated with climate change.

In conclusion, ocean acidification together with ocean change can act in the marine environment synergistically or antagonistically to affect diatom performance, depending on the levels of sunlight [14]. Intensified stratification may push the marine phytoplankton into nitrogen-limited status, and will thereby influence the physiological or biochemical characteristics of the phytoplankton cells. Increases in respiratory metabolism may counteract any increase in the rate of $\mathrm{C}$ gain through photosynthesis (and hence affect net growth) [11], [14], [36]. Enhanced $\mathrm{C}: \mathrm{N}$ ratios, induced by high $\mathrm{CO}_{2}$ and low nitrogen, can influence secondary producers as well as predators at higher levels. Effects of ocean acidification on marine primary producers can be speciesspecific due to their physiological diversities and vary between different oceanic regions correlated with differed physical, chemical or biological conditions.

\section{Acknowledgments}

We thank the anonymous reviewers for their constructive comments.

\section{Author Contributions}

Conceived and designed the experiments: KSG. Performed the experiments: WL. Analyzed the data: WL KSG JB. Contributed reagents/ materials/analysis tools: WL. Wrote the paper: WL KSG JB.

11. Wu Y, Gao K, Riebesell U (2010) $\mathrm{CO}_{2}$-induced seawater acidification affects physiological performance of the marine diatom Phaeodactylum tricornutum. Biogeosciences 7: 2915-2923.

12. Pörtner HO, Farrell AP (2008) Physiology and climate change. Science 322: 690-692.

13. Veron JEN, Hoegh-Guldberg O, Lenton TM, Lough JM, Obura DO, et al. (2009) The coral reef crisis: The critical importance of $<350 \mathrm{ppm} \mathrm{CO}_{2}$. Mar Pollut Bull 58: 1428-1436.

14. Gao K, Xu J, Gao G, Li Y, Hutchins DA, et al. (2012) Rising $\mathrm{CO}_{2}$ and increased light exposure synergistically reduce marine primary productivity. Nature climate change 2: 519-523.

15. Caraco N, Cole J, Likens GE (1990) A comparison of phosphorus immobilization in sediments of freshwater and coastal marine systems. Biogeochemistry 9: 277-290.

16. Doney SC (2006) The dangers of ocean acidification. Sci Am 294: 58-65.

17. Cermeño P, Dutkiewicz S, Harris RP, Follows M, Schofield O, et al. (2008) The role of nutricline depth in regulating the ocean carbon cycle. Proc Natl Acad Sci 105: 20344-20349.

18. Shi D, Xu Y, Hopkinson BM, Morel FMM (2010) Effect of ocean acidification on iron availability to marine phytoplankton. Science 327: 676-679.

19. Beman JM, Chow CE, King AL, Feng Y, Fuhrman JA, et al. (2011) Global declines in oceanic nitrification rates as a consequence of ocean acidification. Proc Natl Acad Sci 108: 208-213. 
20. Hipkin CR, Thomas RJ, Syrett PJ (1983) Effects of nitrogen deficiency on nitrate reductase, nitrate assimilation and photosynthesis in unicellular marine algae. Mar Biol 77: 101-105.

21. Kaffes A, Thoms S, Trimborn S, Rost B, Langer G, et al. (2010) Carbon and nitrogen fluxes in the marine coccolithophore Emiliania huxleyi grown under different nitrate concentrations. J Exp Mar Biol Ecol 393: 1-8.

22. Beardall J, Sobrino G, Stojkovic S (2009) Interactions between the impacts of ultraviolet radiation, elevated $\mathrm{CO}_{2}$, and nutrient limitation on marine primary producers. Photoch Photobio Sci 8: 1257-1265.

23. Burkhardt S, Zondervan I, Riebesell U (1999) Effect of $\mathrm{CO}_{2}$ concentration on $\mathrm{C}: \mathrm{N}: \mathrm{P}$ ratio in marine phytoplankton: A species comparison. Limnol Oceanogr 44: 683-690.

24. Sobrino C, Ward ML, Neale PJ (2008) Acclimation to elevated carbon dioxide and ultraviolet radiation in the diatom Thalassiosira pseudonana: Effects on growth, photosynthesis, and spectral sensitivity of photoinhibition. Limnol Oceanogr 53: 494-505.

25. Morel FMM, Rueter JG, Anderson DM, Guillard RRL (1979) Aquil: A chemically defined phytoplankton culture medium for trace metal studies. J Phycol 15: 135-141.

26. Lewis E, Wallace DWR (1998) Program developed for $\mathrm{CO}_{2}$ system calculations. ORNL/CDIAC-105. Carbon Dioxide Information Analysis Center, Oak Ridge National Laboratory, US Department of Energy, Oak Ridge, Tennessee.

27. Roy RN, Roy LN, Vogel KM, Porter-Moore C, Pearson T, et al. (1993) The dissociation constants of carbonic acid in seawater at salinities 5 to 45 and temperatures 0 to $45^{\circ} \mathrm{C}$. Mar Chem 44: 249-267.

28. Dickson AG (1990) Standard potential of the reaction: $\mathrm{AgCl}(\mathrm{s})+1 / 2 \mathrm{H}_{2}(\mathrm{~g})=$ $\mathrm{Ag}(\mathrm{s})+\mathrm{HCl}(\mathrm{aq})$, and the standard acidity constant of the ion $\mathrm{HSO}_{4}{ }^{-}$in synthetic seawater from 273.15 to $318.15 \mathrm{~K}$. J Chem Thermodyn 22: 113-127.

29. Porra RJ (2002) The chequered history of the development and use of simultaneous equations for the accurate determination of chlorophylls a and $\mathrm{b}$. Photosynth Res 73: 149-156.

30. Ritchie RJ (2006) Consistent sets of spectrophotometric chlorophyll equations for acetone, methanol and ethanol solvents. Photosynth Res 89: 27-41.

31. Strickland JDH, Parsons TR (1968) A practical handbook of seawater analysis. B Fish Res Board Can 167: 49-80.

32. Eilers PHC, Peeters JCH (1988) A model for the relationship between light intensity and the rate of photosynthesis in phytoplankton. Ecol Model 42: 199215.

33. Burkhardt S, Riebesell U, Zondervan I (1999) Effects of growth rate, $\mathrm{CO}_{2}$ concentration, and cell size on the stable carbon isotope fractionation in marine phytoplankton. Geochim Cosmochim Acta 63: 3729-3741.

34. Trimborn S, Lundholm N, Thoms S, Richter KU, Krock B, et al. (2008) Inorganic carbon acquisition in potentially toxic and non-toxic diatoms: the effect of $\mathrm{pH}$-induced changes in seawater carbonate chemistry. Physiol Plantarum 133: 92-105.

35. Burkhardt S, Amoroso G, Riebesell U, Sültemeyer D (2001) $\mathrm{CO}_{2}$ and $\mathrm{HCO}_{3}{ }^{-}$ uptake in marine diatoms acclimated to different $\mathrm{CO}_{2}$ concentrations. Limnol Oceanogr 46: 1378-1391.

36. Yang G, Gao K (2012) Physiological responses of the marine diatom Thalassiosira pseudonana to increased $\mathrm{pCO}_{2}$ and seawater acidity. Mar Environ Res 10.1016/ j.marenvres.2012.06.002.
37. Larsson M, Larsson CM, Guerrero MG (1985) Photosynthetic nitrogen metabolism in high and low $\mathrm{CO}_{2}$-adapted Scenedesmus.II: Effect of ammonium and methionine sulphoximine on nitrate utilization. J Exp Bot 36: 1387-1395.

38. Gordillo FJL, Figuéroa FL, Niell FX (2003) Photon- and carbon-use efficiency in Ulva rigida at different $\mathrm{CO}_{2}$ and $\mathrm{N}$ levels. Planta 218: 315-322.

39. Beardall J, Young E, Roberts S (2001) Approaches for determining phytoplankton nutrient limitation. Aquat Sci 63: 44-69.

40. Allen AE, Dupont CL, Oborník M, Horák A, Nunes-Nesi A, et al. (2011) Evolution and metabolic significance of the urea cycle in photosynthetic diatoms. Nature 473: 203-207.

41. Doucette GJ, Harrison PJ (1990) Some effects of iron and nitrogen stress on the red tide dinoflagellate Gymnodinium sanguineum. Mar Ecol Prog Ser 62: 293-306.

42. Riegman R, Stolte W, Noordeloos AAM, Slezak D (2000) Nutrient uptake and alkaline phosphatase (EC 3: 1: 3: 1) activity of Emiliania huxleyi (Prymnesiophyceae) during growth under $\mathrm{N}$ and $\mathrm{P}$ limitation in continuous cultures. J Phycol 36: 87-96.

43. Litchman E, Neale PJ, Banaszak AT (2002) Increased sensitivity to ultraviolet radiation in nitrogen-limited dinoflagellates: Photoprotection and repair. Limnol Oceanogr 47: 86-94.

44. Trimborn S, Wolf-Gladrow D, Richter KU, Rost B (2009) The effect of $\mathrm{pCO}_{2}$ on carbon acquisition and intracellular assimilation in four marine diatoms. J Exp Mar Biol Ecol 376: 26-36.

45. Young EB, Beardall J (2005) Modulation of photosynthesis and inorganic carbon acquisition in a marine microalga by nitrogen, iron, and light availability. Can J Bot 83: 917-928.

46. Beardall J, Griffiths H, Raven J (1982) Carbon isotope discrimination and the $\mathrm{CO}_{2}$ accumulating mechanism in Chlorella emersonii. J Exp Bot 33: 729-737.

47. Beardall J, Giordano M (2002) Ecological implications of microalgal and cyanobacterial $\mathrm{CO}_{2}$ concentrating mechanisms, and their regulation. Funct Plant Biol 29: 335-347.

48. Pörtner HO, Dupont S, Melzner F, Storch D, Thorndyke M (2010) Studies of metabolic rate and other characters across life stages. In: Riebesell U, Fabry VJ, Hansson L, Gattuso J-P, editors. Guide to best practices ocean acidification and data reporting. Luxembourg: Publications Office of the European Union. 137165.

49. Flynn KJ, Blackford JC, Baird ME, Raven JA, Clark DR, et al. (2012) Changes in $\mathrm{pH}$ at the exterior surface of plankton with ocean acidification. Nature climate change 2: 510-513.

50. Wichard T, Gerecht A, Boersma M, Poulet S, Wiltshire K, et al. (2007) Lipid and fatty acid composition of diatoms revisited: rapid wound-activated change of food quality parameters influences herbivorous copepod reproductive success. Chembiochem 8: 1146-1153.

51. Rossoll D, Bermúdez R, Hauss H, Schulz KG, Riebesell U, et al. (2012) Ocean acidification-induced food quality deterioration constrains trophic transfer. PLoS ONE 7: e34737

52. Riebesell U, Schulz KG, Bellerby RGJ, Botros M, Fritsche P, et al. (2007) Enhanced biological carbon consumption in a high $\mathrm{CO}_{2}$ ocean. Nature 450: 545-549. 